\title{
Influence of Seed Age on Germination and Seeding Vigour of Aonla
}

\author{
S.K. Purbey ${ }^{*}$, Rahul Dev ${ }^{2}$ and S.P. Vyas ${ }^{2}$ \\ ${ }^{1}$ ICAR-NRC on Litchi, Muzaffarpur, India \\ ${ }^{2}$ CAZRI, RRS, Kukma, Bhuj, Gujarat, India \\ *Corresponding author
}

\section{A B S T R A C T}

\begin{tabular}{|l|}
\hline Ke y w o r d s \\
Germination, Vigour, \\
Seed, Storage
\end{tabular}

\section{Introduction}

Aonla (Emblica officinalis Gaertn) owing to hardy nature, adoptability to various degraded lands, high production potential, nutritive and therapeutic value, have become an important fruit crop of the arid region (Sharma. 2004). The area under aonla cultivation is continuously increasing since last 10 years. Aonla is commercially propagated through budding of rootstock. High seed quality is essential for raising of quality rootstock. But, it has been observed that there is less availability of quality planting material, due to lack of reliable information on the effect of storage on germination behaviour and seedling attributes, which is known to deteriorate under normal conditions of storage (Agrawal, 1982). Thus, an understanding of the effect of storage period on seed quality of aonla in terms of viability, germination and vigour attributes is needed to develop quality seedlings for successful establishment of aonla plantations. Such information would also be highly useful for those who are engaged in mass multiplication of aonla seedlings. Present investigation was therefore, under taken with the objective to gain the information in this regard.

\section{Materials and Methods}

An experiment was conducted at research farm of CAZRI, Kukma, Bhuj (Gujarat) for a period from Feb. to March 2005-06. The aonla seeds were extracted from fully ripened deshi fruits harvested in last week of January and stored in plastic container at ambient 
condition. The seeds were socked in $1 \%$ $\mathrm{KNO}_{3}$ solution for $24 \mathrm{hrs}$ and sown in polythene bags of 9" X 4" size, filled with nursery soil. The seeds were sown at monthly interval to study the seed longevity. The experiment was laid out in RBD with three replications, each having 25 polythene tubes. The observations on seed germination were recorded from $5^{\text {th }}$ day of sowing to the completion of germination.

The height of the seedlings and number of leaf lets were recorded at 90 DAS. Germination speed and vigour index were calculated using following formula:

Germination speed = Germination percent $/$ Days taken for complete germination.

Vigour index $=$ Germination percent $\mathrm{X}$ Seedling height

The results were statistically analyzed.

\section{Results and Discussion}

The mean monthly temperature and humidity data recorded during the experimental period are shown in table 1 . The maximum temp $\left(37.64^{\circ} \mathrm{C}\right)$ and humidity $(84.5 \%)$ was recorded during April- May and Aug-Sept. respectively whereas minimum temp. $\left(15.25^{\circ}\right)$ and humidity $(25.66 \%)$ was recorded during Oct-
Nov. It is evident from the data (Table 2) that storage under ambient condition had significantly affected the days taken to initiate germinations, germination percentage and vigour of the seedlings. The mean days for germination have progressively increased as the seeds became aged. Maximum time was taken to initiate germination in 10 months old seed (i.e. 28.67 days). This might also be due to low temperature in winter season.

The presented data (Table 2 and 3) also indicates that ageing of seed caused loss of germination percentage and germination speed with maximum germination $(88.67 \%)$ and speed $(6.35 \%$ day) was registered when seeds were sown just after extraction. Thereafter, the loss of germination was comparable up to $7^{\text {th }}$ month of storage but there was more pronounced reduction in germination $(73.7 \%)$ on $10^{\text {th }}$ month onwards storage of seed. These findings are similar to those of Kadam et al., (1995) and Kumar and Majmudar (1993) who also reported that germination decline steadily in seeds of many citrus stored under ambient condition. It might be due to decline in capacity for synthesis of protein, lipid and RNA, injury to membrane and chromosomes as well as decreased repair system (Osborne, 1980 and Thakur et al., 1997). Up to $5^{\text {th }}$ month of seed age, there was no significant effect on seedling height and number of leaf lets/plant.

Table.1 Mean monthly weather data of experimental period

\begin{tabular}{|c|c|c|c|c|}
\hline Month & \multicolumn{2}{|c|}{ Temperature (oC) } & \multicolumn{2}{|c|}{ Humidity (\%) } \\
\hline & Maxm. & Minm. & Maxm. & Minm. \\
\hline Feb.-March & 34.86 & 18.46 & 57.18 & 30.43 \\
\hline April-May & 37.64 & 25.29 & 74.28 & 37.24 \\
\hline June-July & 35.06 & 28.60 & 76.43 & 51.63 \\
\hline Aug.-Sept. & 33.19 & 25.00 & 84.50 & 59.65 \\
\hline Oct.-Nov. & 34.26 & 22.15 & 56.54 & 25.66 \\
\hline Dec.-Jan. & 27.36 & 15.25 & 66.77 & 43.80 \\
\hline Feb.-March & 31.40 & 17.17 & 70.44 & 28.81 \\
\hline
\end{tabular}


Table.2 Effect of seed age on germination and seedling vigour of aonla

\begin{tabular}{|l|c|c|c|c|}
\hline $\begin{array}{c}\text { Seed age } \\
\text { (Month) }\end{array}$ & $\begin{array}{c}\text { Days taken for } \\
\text { germination }\end{array}$ & $\begin{array}{c}\text { Germination } \\
\text { percent }\end{array}$ & $\begin{array}{c}\text { Germination } \\
\text { speed }\end{array}$ & Vigour index \\
\hline $\mathbf{0 - 1}$ & 6.67 & 88.67 & 6.35 & 2612.40 \\
\hline $\mathbf{2 - 3}$ & 6.34 & 77.34 & 5.33 & 2204.87 \\
\hline $\mathbf{4 - 5}$ & 7.00 & 77.00 & 5.05 & 2123.13 \\
\hline $\mathbf{6 - 7}$ & 10.22 & 73.34 & 4.08 & 1579.93 \\
\hline $\mathbf{8 - 9}$ & 16.67 & 66.00 & 2.54 & 734.90 \\
\hline $\mathbf{1 0 - 1 1}$ & 28.67 & 23.34 & 0.73 & 242.93 \\
\hline $\mathbf{1 1 - 1 2}$ & 18.34 & 26.00 & 1.00 & 381.43 \\
\hline Mean & 13.42 & 61.72 & 3.58 & 1411.37 \\
\hline CD at 5\% & 1.37 & 4.44 & 0.34 & 140.40 \\
\hline
\end{tabular}

Table.3 Effect of seed age on germination and seedling vigour of Aonla 90 DAS

\begin{tabular}{|l|c|c|c|}
\hline $\begin{array}{c}\text { Seed age } \\
\text { (Month) }\end{array}$ & $\begin{array}{c}\text { Seedling height } \\
(\mathbf{c m})\end{array}$ & No. of leaflets & $\begin{array}{c}\text { Collar diameter } \\
(\mathbf{c m})\end{array}$ \\
\hline $\mathbf{0 - 1}$ & 29.45 & 28.95 & 0.53 \\
\hline $\mathbf{2 - 3}$ & 28.48 & 26.92 & 0.49 \\
\hline $\mathbf{4 - 5}$ & 27.47 & 28.47 & 0.47 \\
\hline $\mathbf{6 - 7}$ & 21.52 & 20.06 & 0.50 \\
\hline $\mathbf{8 - 9}$ & 11.10 & 10.20 & 0.45 \\
\hline $\mathbf{1 0 - 1 1}$ & 10.34 & 10.05 & 0.44 \\
\hline $\mathbf{1 1 - 1 2}$ & 14.65 & 13.30 & 0.45 \\
\hline Mean & 20.43 & 19.61 & 0.47 \\
\hline CD at 5\% & 2.18 & 2.03 & NS \\
\hline
\end{tabular}

But, then after significant decrease in plant vigor was observed with increase in period of storage. Similarly, there was pronounced effect of seed storage period on vigour index, which was maximum (2612.40) in freshly extracted seed. Sammour R.H. (1989) also observed decline in vigour of aged seeds of linum which was correlated with degradations of protein and decrease activity of related enzymes. However, the mechanism underlying the decline in germinability and seedling vigour remains to be understood in this important fruit plant.

On the basis of above observations it may be concluded that seed can be stored up to 9 month under ambient storage for propagation of aonla seedling. The study also points to identify proper storage method and chemical priming of seed, which can help to maintain the germination and vigour potential of aged seeds.

\section{References}

Agrawal, P.K. 1982. Viability of stored seed and magnitude of seed storage in India. Seed Technol. News 12(1): 47.

Kadam, A.S., Khedkar, D.M. Patil, V.K. and Anserwadekar, K.W. 1994. Studies on viability and germinability of Rangpur lime seeds during storage. J. Maharashtra Agril, Univ. 19: 130-131. 
Kumar, B.P. and Majumdar, A. M. 1993. A note on the viable period of Kagzi lime seeds (Citrus aurantifolia swingle). Lal Bag, 18: 46-47.

Osborne, D.J. 1998. Senescence in seed. In K.V. Thimann (ed) Senescence in Plants, CRC Press Boca Raton, Florida, pp 13-37.

Sammour, R.H. 1989. Effect of ageing on carbohydrate, Proteins and their related enzymes in natural aged seeds of flax. Pakistan J. Biochem. 22(2): 81-87.
Suneel Sharma, 2004. Under exploited flora of arid ecosystem. In: P.L. Saroj, B.B. Vashishtha and D. G. Dhandar (ed), Advances in Arid Horticulture, pp 113125.

Thakur, Anju, Thakur, P. S. and Bhardwaj, J. 1997. Influence of seed osmoconditioning on germination potential and performance of bell pepper. Seed Research, 25: 25-30.

\section{How to cite this article:}

Purbey, S.K., Rahul Dev and Vyas, S.P. 2018. Influence of Seed Age on Germination and Seeding Vigour of Aonla. Int.J.Curr.Microbiol.App.Sci. 7(10): 1888-1891.

doi: https://doi.org/10.20546/ijcmas.2018.710.217 